\title{
THE ONLINE LISTENING STRATEGY INSTRUCTION AND VOCABULARY KNOWLEDGE ON LISTENING SKILL OF GRADE 12 JAPANESE LANGUAGE LEARNERS IN BEKASI WEST JAVA
}

\author{
Fitri Astar, Yumna Rasyid, Siti Ansoriyah \\ Universitas Negeri Jakarta \\ FitriAstar_7316168005@mhs.unj.ac.id \\ Yumna Rasyid \\ Universitas Negeri Jakarta \\ yumna_rasyid@unj.ac.id \\ Siti Ansoriyah \\ Universitas Negeri Jakarta \\ siti.ansoriyah@unj.ac.id
}

Accepted: 2021-06-15, Approved: 2021-07-01, Published: 2021-07-05

\section{ABSTRACT}

This article presents the result of empirical research that investigates the effect of online listening strategies instruction and vocabulary knowledge on Japanese language learners' listening skill. Listening strategies instruction used are the integrative model and the Oxford model. Participants in the study were 44 Japanese language learners of grade 12 from SMAN 21 Bekasi. This research used a quantitative approach and a quasi-experimental method. The data was collected by pre-test and post-test related to the learners' Japanese listening skills. The learners' vocabulary knowledge was also measured using a vocabulary knowledge test. The result showed that the online listening strategy instruction, integrative model could not be given to students of class XII of SMAN 21 Bekasi due to the absence of a significant effect of the method and vocabulary knowledge on listening skills of Japanese language learners of grade 12 from SMAN 21 Bekasi. The research shows the possibility of other factors such as learning independency and learner autonomy that can affect the effectiveness of online listening strategy instruction, integrative model on Japanese listening skills.

Keywords: Listening Strategy Instruction; Listening Skill; Vocabulary Knowledge; Japanese language.

\section{INTRODUCTION}

In daily life communication activities, more than $50 \%$ of the time was used for listening (Yokoyama, 2008). Listening can be said, compared to the other three skills, speaking, reading, and writing, dominate the daily communication activities. However, this is contrary to the reality of listening skills in language learning and research. Nunan (2002) used the term Cinderella skill in second language learning when talking about listening skills. Listening is often underestimated when is compared to the other skills. Most people consider knowledge of a second language is to be able to speak and write in that language, whereas listening is more often seen as a skill that learners naturally possess. This has an impact on the small portion of listening both in learning and in research. 
In recent years, listening skill began to show its role like the three other skills (Field, 2002; Richards, 2005; Vandergrift, 2004). Along with the increasing role of listening for language learners, especially second and foreign language, method that can develop and improve listening skills is needed.

Some experts proposed strategy instruction as an alternative that can be used in listening instruction. Strategy training is useful in increasing awareness of the use of strategies, giving learners the opportunity to practice strategies that have been taught, and helping them to use strategies in various learning contexts (Cohen, 2003) .

According to Oxford (2003), there are many evidences that developed and indicated that teachers need to do strategy instruction. Oxford proposed an explicit listening strategy instruction. According to Oxford, a comprehensive listening strategy instruction. This model focuses on the importance of raising learners' awareness of learning strategies and making them to become independent learners (Guan, 2014; R. Oxford et al., 1990).

Vandergrift (2007) also proposed listening strategy isntruction which he called the integrative model. Vandergrift's model uses a pedagogic cycle that can help language learners to use bottomup $(B U)$ and top-down (TD) strategies as well as the metacognitive awareness needed for successful listening. Vandergrift \& Tafaghodtari (2010) conducted a study which showed that learners made progress in listening significantly more than learners in the comparison group. The less proficient group in the experimental class also showed higher improvement than the more proficient group. So, it can be said that this method is also effective in less proficient learners.

Vocabulary Knowledge is an important aspect in listening skills. Meccarty in Vandergrift (2004) found that both grammar and vocabulary knowledge were significantly related to listening comprehension, but vocabulary knowledge was more likely to be related. Then, Wang and Treffers-Daller (2017) in their research showed that vocabulary knowledge is the strongest predictor of listening comprehension, compared to the other two variables, general language skills and metacognitive awareness.

Based on the explanation above, it can be said that a research is needed to prove that this method can be used and useful for listening instruction. Therefore, this research is conducted to determine the effect of online listening strategy isntruction and vocabulary knowledge on listening skills of grade 12 Japanese language learners of SMAN 21 Bekasi. The treatment in this research is carried out in online mode due to the Covid-19 pandemic situation which is still ongoing today. In accordance with the SE No. 4 of 2020 concerning the implementation of education policies in the emergency period of the spread of Covid19 , the learning process is carried out at home and through online distance learning.

\section{Listening Strategy Instruction}

Strategy instruction was originally an investigation related to "good" language learners (Chamot, 2005; Graham \& Macaro, 2008; Griffiths, 2004; Oxford, 2003; Vandergrift $\dagger$ and Cross, 2018). By investigating the strategies used by language learners during the learning process, also the differences between strategies used by more effective learners compared to less efective learners (Chamot, 2005), teachers can help learners to become better and 
efficient, especially in increasing their autonomy in learning language(Brown, 2007; Graham \& Macaro, 2008) .

Oxford (2003) formulated a second language learning strategy as a process of thinking or specific behavior that learners use to improve their second language learning. According to Oxford, a strategy can be effective if 1) it is closely related to second language tasks, 2) it is in accordance with the characteristics of the learners' learning style, and 3) the learners can utilize the strategy effectively and relate it to other related strategies.

When the three conditions above are met, strategies can make learning language becomes easier, faster, fun, and effective. However, not all learners understand the learning strategies they can use in listening. An expert teacher can help learners to raise awareness and use various strategies based on their needs (RL Oxford, 2003). Learning strategies can also make learners more independent, autonomous, and become lifelong learners (Allwright and Litle in RL Oxford, 2003).

\section{Listening Strategy Instruction, Integrative Model}

This model is called integrative because according to (Vandergrift, 2007) this strategy instruction combined $B U$ and $T D$ processes and integr ated metacognitive awareness which is important for the success of listening activities. This can be seen in the pedagogic cycle he developed.

Table 1: Vandergrift's Integrative Model Pedagogic Cycle

\begin{tabular}{|l|ll|}
\hline $\begin{array}{l}\text { Planning/Predicting Stage } \\
\text { 1. Once learners know the topics and types of text, they can } \\
\text { predict the types of information and vocabulary they might hear }\end{array}$ & $\begin{array}{l}\text { Planning } \\
\text { attention }\end{array}$ & and directed \\
\hline $\begin{array}{l}\text { First Verification Stage } \\
\text { 2. Learners listen to verify initial hypotheses, correct areas } \\
\text { that need improvement, and record other information captured }\end{array}$ & Monitoring & \\
$\begin{array}{l}\text { 3. Learners compare what they have recorded with their peers, } \\
\text { modify parts that need modification, and decide on important } \\
\text { details that still require special attention. }\end{array}$ & $\begin{array}{l}\text { Monitoring, planning and } \\
\text { selective attention }\end{array}$ \\
\hline $\begin{array}{l}\text { Second Verification Stage } \\
\text { 4. Learners pay attention to parts where they found different, } \\
\text { make corrections, and write down additional details that are } \\
\text { understood. }\end{array}$ & $\begin{array}{l}\text { Monitoring and } \\
\text { solving }\end{array}$ & problem \\
$\begin{array}{l}\text { 5. Class discussion can be started in which all class members } \\
\text { contribute in reconstructing the main points of the text and } \\
\text { relevant details, along with reflections about how the learner } \\
\text { arrives at understanding certain vocabulary from the text they } \\
\text { listened to }\end{array}$ & Monitoring and evaluation \\
\hline $\begin{array}{l}\text { Final Verification Stage } \\
\text { 6. Learners listen to information that appears during class } \\
\text { discussions that they could not catch before, comparing all or } \\
\text { some parts of the oral text with a transcript of the text. }\end{array}$ & $\begin{array}{l}\text { Selective } \\
\text { monitoring }\end{array}$ & attention \\
\hline $\begin{array}{l}\text { Reflection Stage } \\
\text { 7. Based on the previous discussion regarding the parts that } \\
\text { were not captured while listening, learners wrote their hopes for } \\
\text { the next listening activity. Discussions related to the differences } \\
\text { that exist between oral and written texts can also be carried out at } \\
\text { this stage. }\end{array}$ & Evaluation & \\
\end{tabular}


In this pedagogic cycle, Vandergrift "orchestrated" the use of hypotheses and verification and applies background knowledge to fill understanding gaps that occured so that learners can gain knowledge about the listening process.

\section{Listening Strategy Instruction, Oxford Model}

According to Oxford (2003) first and second language research showed that learning strategy training will be effective if it is explicit where learners are given an explanation that certain behaviors or strategies are useful and they are trained how to use and utilize them in appropriate situations. The training that is implicit in which learners are given one particular strategy without knowing the purposes of the strategy would be less likely to succeed. Strategy training will also be successful when is combined with the learning pocess carried out in the classroom.

The stages of listening strategy instruction, Oxford model are as follows:

(1) Learners are asked to do one task without being preceed by learning strategies; the teacher asks them to discuss and reflect on how they completed the activity

(2) The teacher models the strategies needed, explains the benefits of these strategies and ensures learners can understand the purpose of using those strategy

(3) Learners are given many opportunities to practice using new strategies and learn how a strategy can also be used in other

tasks

(4) The teacher provides further assignments; learners make choices on the strategies that will be used to complete the task assigned

(5) Teachers help learners to evaluate the use of the strategies and their progress in using them independently (Guan, 2014; R. Oxford et al., 1990).

The listening strategy instruction is carried out in online mode synchronously and unsynchronously using the internet and various applications and platforms, such as Google Meet, Google Forms, Microsoft Powerpoint, Google Classroom and Whatsapp, which support the effectiveness of online listening strategies instruction.

\section{Vocabulary Knowledge}

$$
\text { Vocabulary }
$$

is an important element in

knowledge listening instruction, because there is a strong relationship between the ease of accessing vocabulary with the effective listening activities (Rost, 2011).

Listening is influenced by someone vocabulary capacity and also the ability to recognize words in speech. Activation of knowledge (content schemata and cultural schemata), which is required in understanding discourse is related to and influenced by word recognition (Rost, 2011). According to Segalowitz et al., and Laufer and Hulstjin in Rost (2011), speed and breadth in the ability to recognize words are good predictors of listening ability. In addition, Rost, Nation et.al., and Graves in Rost (2011) prove that the inability to understand words in oral texts can cause attention problems that will affect the 
listener's understanding, either directly or indirectly.

$$
\text { According to Rost (2011), }
$$
vocabulary knowledge consists of a surface level (syntax) which includes recognition of the spoken form of the vocabulary (including variations in allophones), its written form and grammatical function, and a deeper level (paradigmatic) which includes word collocation, relative frequency in language, usage restrictions, and denotations and connotations.

Vocabulary knowledge consists of a surface level and a deeper level so that there are productive vocabulary term and also receptive vocabulary. In the explanation by Richards \& Schmidt (2010), the term refers to the amount of vocabulary that a person actively uses, compared to the amount of vocabulary they know and understand but are not actively used. A person can understand more words than words they are actively using. He can have a receptive vocabulary (vocabulary they can understand in reading or listening) of up to 100,000 words, but productive vocabulary (for example those they use in writing or speaking) is only about 10,000 to 20,000 words.

Stæhr (2009), in his research, used the term breadth and depth of vocabulary mastered by learners to describe vocabulary knowledge. These two terms more or less refer to the same thing that Richards \& Schmidt described regarding receptive and productive vocabulary. According to Staehr, vocabulary breadth refers to the large number of vocabulary that is mastered by the learner, while the depth of vocabulary reflects how well the learners know each vocabulary or in other words how well the vocabulary is arranged in the learners' mental state regarding its meaning and association.

\section{Research Questions}

This research is based on previous studies and continued to investigate the effect of online listening strategy instruction and vocabulary knowledge on listening skills of grade 12 Japanese language learners of SMAN 21 Bekasi.

1. Is there any difference of listening skill of Japanese language learners who get to use online listening strategies instruction, integrative model and online listening strategies instruction, Oxford model?

2. Is there any difference of listening skill of Japanese language learners with high vocabulary knowledge who get to use online listening strategies instruction, integrative model and online listening strategies instruction, Oxford model?

3. Is there any difference of listening skill of Japanese language learners with low vocabulary knowledge who get to use online listening strategies instruction, integrative model and online listening strategies instruction, Oxford model?

4. Is there any interaction between online listening srtategy instruction and vocabulary knowledge on learners' Japanese listening skill?

\section{METHOD}

This research used a quantitative approach, an experimental method with independent variables namely the listening strategy instruction

method (online listening strategy instruction, integratif model and online listening strategy instruction, Oxford model) and vocabulary knowledge and the dependent variable of Japanese listening skill. Other variables that are thought to affect the dependent variable will be controlled by external validity and internal validity. Participants in this study were 
44 students of grade 12 from SMAN 21 Bekasi.

To see the changes before and after treatment given, researchers conducted tests (Gay, Mills, \& Airasian, 2012) using two instruments that measure learners' Japanese language listening skill and vocabulary knowledge. The listening skill instrument consists of 15 multiple choice questions and short answers and the vocabulary

knowledge instrument consists of 19 multiple choice questions.

The test results were tested for normality and homogeneity using SPSS the Kolmogorov-Smirnov

and Levene formula. Afterward, researcher used the SPPS application with the t-test and ANOVA technique to see the effect of independent variables on the dependent variable.

\section{RESULT AND DISCUSSION Result}

\section{Descriptive Data Analysis Result}

Analysis of the pre-test results showed the highest score, lowest score, mean, and standard deviation in the experimental and control classes. In the experimental class, the highest pre-test score was 90 and the lowest score was 52 . The mean score of the pre-test was 72 and the standard deviation was 10.7. While the post-test results show the highest score was 92 and the lowest score was 40. The average value of the final test is 75 and the standard deviation 12.5. In the control class, high scores of pre-tests was 92 and the lowest score is 40 . The average value of the pre test was 63 and standard deviation was 14.0. Then, the results of the post-test showed the highest score was 96 and the lowest score was 42. The mean score of the post-test was 69 and the standard deviation was 15.7. The table below shows the results of the learners' pre and

post-tests

Table 2

Comparison of the Results of the Pre-Test and the Post-Test of Listening Skill

\begin{tabular}{lcc}
\hline Experiment Class & Pre-test & Post-test \\
\hline Highest Score & 90 & 93 \\
\hline Lowest Score & 52 & 40 \\
\hline Average & 72 & 75 \\
\hline Standard Deviation & 10.7 & 12,5 \\
\hline Control Class & Pre-test & Post-test \\
\hline Highest Score & 92 & 96 \\
\hline Lowest Score & 40 & 42 \\
\hline Average & 63 & 69 \\
\hline Standard Deviation & 14.0 & 15.7 \\
\hline
\end{tabular}

The frequency distribution of the pre and post-test results is as follows. In the experimental group, pretest scores of $90,85,83,81,80,77,75,65$, 62,58 , and 53 were obtained by one person each and scores of 82, 78, 52 were obtained by two person each. The scores of 71 and 70 were obtained by three person each. The post-test scores of $91,89,83,82$,
$78,77,75,69,65,60,53$ and 40 were obtained by one person each. Scores of 93,79 , and 73 were obtained by two people each and a score of 72 by four people. In the control group, pretest scores of $92,83,81,79,73,72,69,68$, $65,63,61,57,55,54,50,48,45,43$, and 40 were obtained respectively by one person each and a score of 62 was obtained 
BAHTERA: Jurnal Pendidikan Bahasa dan Sastra, Volume 20 Nomor 2 Juli 2021

http://journal.unj.ac.id/unj/index.php/bahtera/

P-ISSN : 0853-2710

E-ISSN : 2540-8968

by two people. In the post-test scores of 96 , $87,86,82,79,76,73,69,67,66,58,56$, 55,46 , and 42 were obtained by one person each. The scores of 85,70 , and 47

Table 3

Frequency Distribution of Initial and Final Test Results

\begin{tabular}{|c|c|c|c|c|c|c|}
\hline \multicolumn{2}{|c|}{ Eksperiment Class } & \multirow{2}{*}{$\begin{array}{c}\text { Pre-test } \\
\begin{array}{c}\text { Number } \\
\text { of Students }\end{array}\end{array}$} & \multicolumn{4}{|c|}{ Post-test } \\
\hline No. & Score & & Percentage & Score & $\begin{array}{c}\text { Number } \\
\text { of Students }\end{array}$ & Percentage \\
\hline 1. & 90 & 1 & $4 \%$ & 93 & 2 & $9 \%$ \\
\hline 2. & 85 & 1 & $4 \%$ & 91 & 1 & $4 \%$ \\
\hline 3. & 83 & 1 & $4 \%$ & 89 & 1 & $4 \%$ \\
\hline 4. & 82 & 2 & $9 \%$ & 83 & 1 & $4 \%$ \\
\hline 5. & 81 & 1 & $4 \%$ & 82 & 1 & $4 \%$ \\
\hline 6. & 80 & 1 & $4 \%$ & 81 & 1 & $4 \%$ \\
\hline 7. & 78 & 2 & $9 \%$ & 79 & 2 & $9 \%$ \\
\hline 8. & 77 & 1 & $4 \%$ & 78 & 1 & $4 \%$ \\
\hline 9. & 75 & 1 & $4 \%$ & 77 & 1 & $4 \%$ \\
\hline 10. & 71 & 3 & $13 \%$ & 75 & 1 & $4 \%$ \\
\hline 11. & 70 & 3 & $13 \%$ & 73 & 2 & $9 \%$ \\
\hline 12. & 65 & 1 & $4 \%$ & 72 & 4 & $17 \%$ \\
\hline 13. & 62 & 1 & $4 \%$ & 69 & 1 & $4 \%$ \\
\hline 14. & 58 & 1 & $4 \%$ & 65 & 1 & $4 \%$ \\
\hline 15. & 53 & 1 & $4 \%$ & 60 & 1 & $4 \%$ \\
\hline 16. & 52 & 2 & $9 \%$ & 53 & 1 & $4 \%$ \\
\hline 17. & & & & 40 & 1 & $4 \%$ \\
\hline \multicolumn{2}{|c|}{ Total } & 23 & $100 \%$ & Total & 23 & $100 \%$ \\
\hline \multicolumn{2}{|c|}{ Control Class } & Pre-test & \multicolumn{4}{|c|}{ Post-test } \\
\hline No. & Score & $\begin{array}{c}\text { Number } \\
\text { of Students }\end{array}$ & Percentage & Score & $\begin{array}{c}\text { Number } \\
\text { of Students }\end{array}$ & Percentage \\
\hline 1. & 92 & 1 & $5 \%$ & 96 & 1 & $5 \%$ \\
\hline 2. & 83 & 1 & $5 \%$ & 87 & 1 & $5 \%$ \\
\hline 3. & 81 & 1 & $5 \%$ & 86 & 1 & $5 \%$ \\
\hline 4. & 79 & 1 & $5 \%$ & 85 & 2 & $10 \%$ \\
\hline 5. & 73 & 1 & $5 \%$ & 82 & 1 & $5 \%$ \\
\hline 6. & 72 & 1 & $5 \%$ & 79 & 1 & $5 \%$ \\
\hline 7. & 69 & 1 & $5 \%$ & 76 & 1 & $5 \%$ \\
\hline 8. & 68 & 1 & $5 \%$ & 73 & 1 & $5 \%$ \\
\hline 9. & 65 & 1 & $5 \%$ & 70 & 2 & $10 \%$ \\
\hline 10. & 63 & 1 & $5 \%$ & 69 & 1 & $5 \%$ \\
\hline 11. & 62 & 2 & $10 \%$ & 67 & 1 & $5 \%$ \\
\hline 12. & 61 & 1 & $5 \%$ & 66 & 1 & $5 \%$ \\
\hline 13. & 57 & 1 & $5 \%$ & 58 & 1 & $5 \%$ \\
\hline 14. & 55 & 1 & $5 \%$ & 56 & 1 & $5 \%$ \\
\hline 15. & 54 & 1 & $5 \%$ & 55 & 1 & $5 \%$ \\
\hline 16. & 50 & 1 & $5 \%$ & 47 & 2 & $10 \%$ \\
\hline 17. & 48 & 1 & $5 \%$ & 46 & 1 & $5 \%$ \\
\hline
\end{tabular}




\begin{tabular}{lcccccc}
\hline 18. & 45 & 1 & $5 \%$ & 42 & 1 & $5 \%$ \\
\hline 19. & 43 & 1 & $5 \%$ & & & \\
\hline 20. & 40 & 1 & $5 \%$ & & & \\
\hline \multicolumn{2}{c}{ Total } & 21 & $100 \%$ & Total & 21 & $100 \%$ \\
\hline
\end{tabular}

The comparison of increasing listening skills (gain score) in the experimental class and the control class on high vocabulary knowledge and low vocabulary knowledge is as follows. The average of increasing in listening skill in the experimental class, on the high vocabulary knowledge group was 1.42 and the standard deviation was 6.61 and on the low vocabulary knowledge group was 4.36 and the standard deviation was 9.05. The average of increasing in listening skill in the control class, on the high vocabulary knowledge group was 8.90 and the standard deviation was 11.69 , and on the low vocabulary knowledge group was 6.64 and the standard deviation was 15.60 . The table below shows this comparison

Table 4

Comparison of the increasing listening skills (gain score) on High Vocabulary Knowledge and Low Vocabulary Knowledge

Improved Listening Skills (pre-test-final test)

Dependent Variable: gain score

\begin{tabular}{llcr}
\hline Group & vocabulary group & Mean & \multicolumn{1}{c}{ Std. Deviation } \\
\hline Experiment & high vocabulary knowledge & 1.4167 & 6.61209 \\
& low vocabulary knowledge & 4.3636 & 9,04735 \\
\hline & vocabulary group & Mean & Std. Deviation \\
\hline Control & high vocabulary knowledge & 8.9000 & 11,68522 \\
& low vocabulary knowledge & 6,6364 & 15,59662 \\
\hline
\end{tabular}

Based on the results of the pre and post-tests on the experimental and control groups, it can be seen that there were changes in each group of test items. In the experimental class, in the first item group about the outline of the content of the text, there was a decrease of $9 \%$. In the group of items on supporting details of the text, there was an increase of $5 \%$. Finally, in the group of items related

Table 5

Comparison of the gain score in each group of listening skills test items

\begin{tabular}{clccc}
\hline Group & \multicolumn{1}{c}{ Test } & Line large text & Supporting detail text & Key words \\
\hline \multirow{4}{*}{ Experiment } & End & 4.17 & 50.35 & 24.17 \\
\cline { 2 - 5 } & Early & 4.61 & 47.13 & 23.96 \\
\cline { 2 - 5 } & Change & -0.43 & 3.22 & 0.22 \\
\cline { 2 - 5 } & in \% & $\mathbf{- 9 \%}$ & $\mathbf{5 \%}$ & $\mathbf{1 \%}$ \\
\hline
\end{tabular}

to keywords in the text, there was an increase of $1 \%$. In the control class, in the first item group about the outline of the content of the text, there was an increase of $5 \%$. In the group of items on supporting details of the text, there was an increase of $4 \%$. Finally, in the group of items related to keywords in the text, there was an increase of $9 \%$. 


\begin{tabular}{llccc}
\hline \multirow{3}{*}{ Control } & End & 4.81 & 48.57 & 18.62 \\
\cline { 2 - 5 } & Early & 4.57 & 45.81 & 15.81 \\
\cline { 2 - 5 } & Change & 0.24 & 2.76 & 2.81 \\
\cline { 2 - 5 } & in \% & $\mathbf{5 \%}$ & $\mathbf{4 \%}$ & $\mathbf{9 \%}$ \\
\hline
\end{tabular}

\section{Data Analysis Requirements Test Results}

The results of the data analysis requirements test related to the normality and homogeneity of the data showed that the data were normally distributed and homogeneous both on the results of the learners' listening skill and vocabulary knowledge tests. Based on these results, hypothesis testing can be performed using the inferential parametric t-test and ANOVA statistical techniques.

In the first hypothesis test, the "Japanese listening skill of the group of

Table 6 learners who used the online listening strategy instruction, integrative model was higher than the group of learners who used the online listening strategy instruction, Oxford model" was carried out using the independent sample t-test technique. The results of hypothesis testing show that $\mathrm{t}$ count of 0.829 is smaller than t table of 1.725 with a sig of 0.412 greater than alpha 0.05 . This causes $\mathrm{Ha}$ rejected and $\mathrm{H}_{0}$ is accepted.

Hypothesis 1 Testing Result

\begin{tabular}{|c|c|c|c|c|c|c|c|c|c|}
\hline & \multicolumn{4}{|c|}{$\begin{array}{l}\text { Levene's Test } \\
\text { for Equality } \\
\text { of Variances }\end{array}$} & \multicolumn{3}{|c|}{ t-test for Equality of Means } & & \\
\hline & \multirow[b]{2}{*}{$\mathrm{F}$} & \multirow[b]{2}{*}{ Sig. } & \multirow[b]{2}{*}{$\mathrm{T}$} & \multirow[b]{2}{*}{$\mathrm{df}$} & \multirow{2}{*}{$\begin{array}{l}\text { Sig. (2- } \\
\text { tailed) }\end{array}$} & \multirow{2}{*}{$\begin{array}{c}\text { Mean } \\
\text { Difference }\end{array}$} & \multirow{2}{*}{$\begin{array}{l}\text { Std. Error } \\
\text { Difference }\end{array}$} & \multicolumn{2}{|c|}{$\begin{array}{l}\text { 95\% Confidence } \\
\text { Interval of the } \\
\text { Difference }\end{array}$} \\
\hline & & & & & & & & Lower & Upper \\
\hline $\begin{array}{r}\text { gain_score Equal } \\
\text { variances } \\
\text { assumed }\end{array}$ & 2,778 & 0.103 & 0.829 & 42 & 0.412 & 2.65424 & 3.20364 & -3.81096 & 9.11945 \\
\hline $\begin{array}{l}\text { Equal } \\
\text { variances } \\
\text { not } \\
\text { assumed }\end{array}$ & & & 0811 & 32,387 & 0.423 & 2.65424 & 3,27324 & -4.01000 & 9.31849 \\
\hline
\end{tabular}

The second hypothesis "Listening skills of Japanese language learners' with high vocabulary knowledge who get online listening strategy instruction, integrative model is higher than the ones who get online listening strategy instruction, Oxford model" test is performed using a technique independent sample t-test. The results of hypothesis testing show that $t$ count of -0.893 is smaller than $t$ table of 1.645 with a sig of 0.382 which is greater than alpha 0.05 so that $\mathrm{Ha}$ is rejected. It means online listening strategy instruction, integrative model is not proven to be better than online listening strategy instruction, Oxford model on the high vocabulary knowledge group.

Table 7

Hypothesis 2 Testing Results 


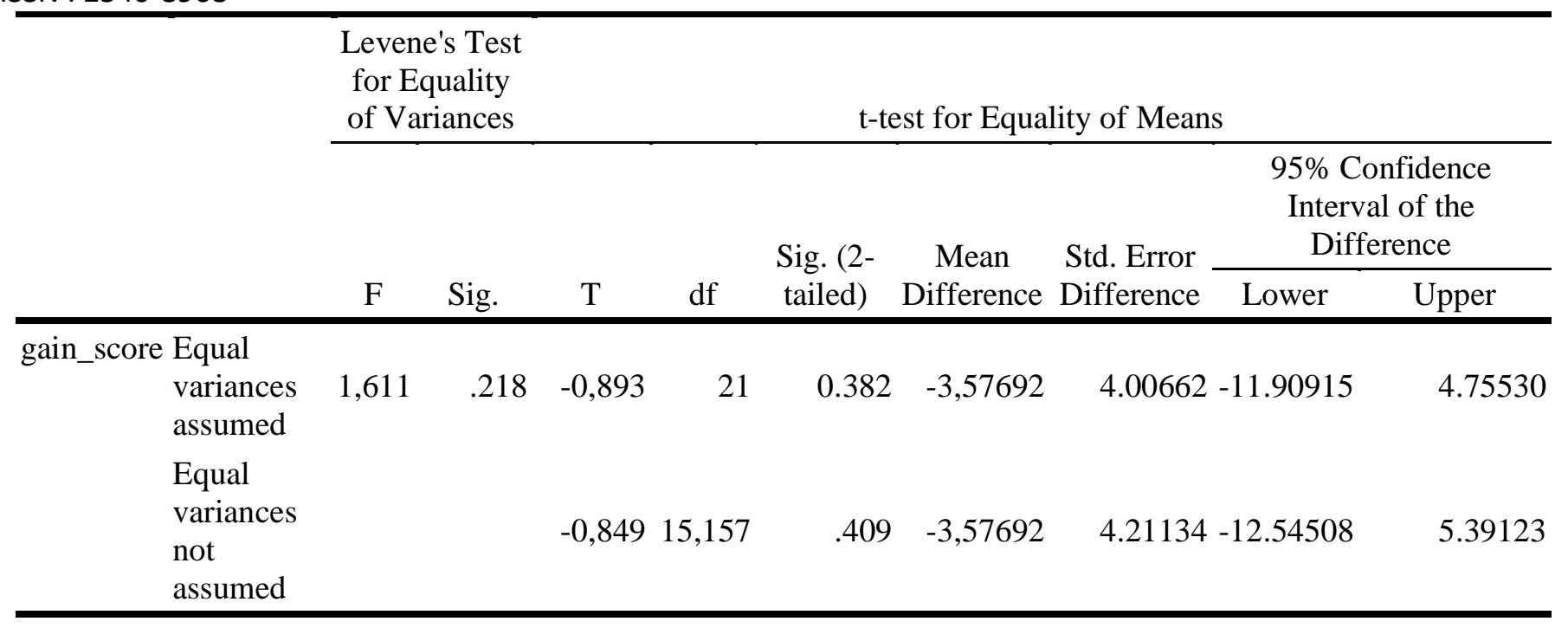

The third hypothesis "Listening skills of Japanese language learners' with low vocabulary knowledge who get online listening strategy instruction, integrative model is higher than the ones who get online listening strategy instruction, Oxford model" test is performed using a technique independent sample t-test. The results of hypothesis testing show that $t$

\section{Table 8}

Hypothesis 3 Testing Results count of -0.297 is smaller than $t$ table 1.645 with a sig of 0.770 greater than alpha 0.05 so that $\mathrm{Ha}$ is rejected and online listening strategy instruction, integrative model is not proven to be better than online listening strategy instruction, Oxford model on low vocabulary knowledge group.

\begin{tabular}{|c|c|c|c|c|c|c|c|c|c|c|}
\hline & & \multicolumn{4}{|c|}{$\begin{array}{c}\text { Levene's Test } \\
\text { for Equality of } \\
\text { Variances } \\
\end{array}$} & \multicolumn{4}{|c|}{ t-test for Equality of Means } & \\
\hline & & \multirow[b]{2}{*}{$\mathrm{F}$} & \multirow[b]{2}{*}{ Sig. } & \multirow[b]{2}{*}{$\mathrm{t}$} & \multirow[b]{2}{*}{ Df } & \multirow{2}{*}{$\begin{array}{l}\text { Sig. }(2- \\
\text { tailed) }\end{array}$} & \multirow{2}{*}{$\begin{array}{c}\text { Mean } \\
\text { Difference }\end{array}$} & \multirow{2}{*}{$\begin{array}{l}\text { Std. Error } \\
\text { Difference }\end{array}$} & \multicolumn{2}{|c|}{$\begin{array}{l}95 \% \text { Confidence Interval } \\
\text { of the Difference }\end{array}$} \\
\hline & & & & & & & & & Lower & Upper \\
\hline \multirow[t]{2}{*}{$\begin{array}{l}\text { gain_- } \\
\text { score }\end{array}$} & $\begin{array}{l}\text { Equal } \\
\text { variances } \\
\text { assumed }\end{array}$ & 2,210 & 0.154 & -0.297 & 19 & 0.770 & $-1,558$ & 5,428 & $-12,544$ & 9,427 \\
\hline & $\begin{array}{l}\text { Equal } \\
\text { variances not } \\
\text { assumed }\end{array}$ & & & -0.305 & 15,492 & 0.764 & $-1,558$ & 5,103 & $-12,405$ & 9,288 \\
\hline
\end{tabular}

The fourth hypothesis "there is an interaction between online listening strategy instruction and vocabulary knowledge on learners' Japanese listening skill" testing was carried out using the twoway ANAVA technique. The results of hypothesis testing show that $\mathrm{f}$ count is 0.122 smaller than $f$ table 8.59 with a sig of
0.729 greater than alpha 0.05 which indicates that there is no interaction between online listening strategy instruction and vocabulary knowledge on Japanese listening skill.

\section{Discussion}

The results of the first hypothesis test indicate that the hypothesis is 
rejected. These results contradict several previous studies. Vandergrift and Tafaghodtari (2010), in his research, presented that participants who use this method shows significant progress in listening and exceed the learners in the control group. The research results are reliable and this method promises to be used in listening instruction. The present study showed different results possibly due to the length of time of the treatment given. Listening strategy instruction in this study was given as much as 5 JP @ 45 minutes. This amount is sufficient by considering Japanese instruction at the school was only once a week.

Jeremy Cross (2011), in his research, gave listening strategy instruction treatment for five times which showed varied results. Chamot and O'Malley et al. (1985) also provided a treatment for 50 minutes in 8 days. Chamot (2005) explained that the ineffective results of research were related partly due to the lack of time given by researchers to practice these strategies.

The treatment in this study was given in online mode due to the Covid-19 pandemic situation that occurred. This research was not easy to do considering that online listening strategy instruction research has not been done much and the school in this study was also conducting distance learning for the first time. Researches related to online distance learning during the pandemic were widely carried out. Several studies have shown positive results in terms of learning outcomes and perceptions of teachers and learners (Almusharraf, Khahro, \& Arabia, 2020; Bernard, Borokhovski, Schmid, Tamim, \& Abrami, 2014). However, some other studies also pointed out the drawbacks of this online distance learning.

Nartiningrum (2020), in her research, revealed that the problems encountered in online learning are unstable connections that reduced direct interaction in learning, decrease of teacher's control and guidance that affected to the decrease of students' commitment for learning. The other problem is learners' concentration that get distracted easily when they start to study or do the assignments. Features in video conferencing applications that are often used in synchronous learning, such as audio and video mute button, can also reduce teacher's control over learners.

The problems encountered by Nartiningrum (2020) in her research were also encountered by researcher during the treatment. Although online learning is said to be an interactive learning, there are still deficiencies in the interaction between teacher and learners. The integrative model of listening strategy instruction is a method that also emphasizes on the interaction of teachers and learners and also gradual instructors' guidance (scaffolding). Researcher find difficulties in interacting and arranging scaffolding due to the lack of response from learners during learning process. Unlike classroom learning, online learning during a pandemic can result in the loss of aspects of scaffolding which causes learners to have difficulty in reaching understanding, especially the one related to a new concept or experience (Owusu-Fordjour, Koomson, \& Hanson, 2020).

Researcher predicted that online listening strategy instruction, integrative model will provide significant results on the listening skills of Japanese learners based on the results of previous studies, such as by Vandergrift and A. Chen. According to Larry Vandergrift (2007), the integrative model of listening strategies instruction is a strategy instruction that attached to the listening learning process in class (implicit), that makes learners absorb and practice easily in using listening

BAHTERA : Jurnal Pendidikan Bahasa dan Sastra, Volume Juli 2021 
strategies. A. Chen (2009) also revealed that implicit listening strategy instruction such as this integrative model would be more effective than the explicit ones. This is because explicit listening trategy instruction has been proven effective in contexts where the learning autonomy and independence of learners are good, for example learners in the western region.

The results of this research are different from

the explanation above. The average of gain score of the class that taken online listening strategy instruction, Oxford model was higher than the class of online listening strategy instruction, integrative model. The possibility of the learning autonomy and independence aspects of needs more attention. Are the learning autonomy and independence of learners in this research good enough so that online listening strategy instruction, Oxford model is more effective than the integrative model? Research on the effect of autonomy and learning independence and the online listening strategy instruction, Oxford model on leraners' Japanese listening skill needs to be carried out in the future.

Based on the result of second hypothesis test, Japanese listening skill of learners with higher vocabulary knowledge after being given the treatment of online listening strategy instruction, integrative model is not proven to be better than the ones that are given online listening strategy instruction, Oxford model. This showed that vocabulary knowledge is not a sufficiently influential variable on the effectiveness of online listening strategy instruction, integrative model.

According to previous studies, groups of learners with high vocabulary knowledge will be easier to understand the aural input they are listening to. This because they can capture words in text quickly and simplify the automation process in understanding a text. However, this is not proven. Jeremy Cross (2011), in his research, also compared the level of learners' language mastery as a moderating variable. Cross found that only one of four advance learners in his study that showed improvement. According to Cross, there may be a tendency of decrease of the effect of the pedagogic cycle on learners' performance along with the increase in their abilities.

Other experts found several other factors that may influence online listening strategy instrucion, namely affective factors such as anxiety, pressure, and resistance; habitual factors, such as learning habits; information processing factor; language proficiency factor; strategy factor; learner confidence factor; and learning material factor. These factors indicate that further and indepth research is needed on listening strategy instruction build on what has been found today as a basis (Cross, 2012).

The third hypothesis is not proven because the listening skills of students with low vocabulary knowledge who got online listening strategy instruction, integrative model are not better than those who got the online listening strategy instruction, Oxford model.

Research by Vandergrift \& Tafaghodtari (2010) showed that the students who are less proficient in the experimental class got better results than those in the control class. The results of this group also exceeded the group of advanced learners in the experimental class. According to Vandergrift, the success of the less proficient learners is caused by the listening strategy instruction that is implicit. Learners focus only on the task assigned and keep practicing. They do this with the guidance of teachers and more proficient colleagues (Goh in Larry Vandergrift \& Tafaghodtari (2010). 
Vandergrift and Tafaghodtari's research was conducted in offline mode. So, scaffolding was easier to do. This research was conducted in online mode that, as previously mentioned, scaffolding is not easy to do, and this is probably one of the factors that causes the results of this research to be insignificant.

The results of this research also showed that there is no interaction between online listening strategy instruction (integrative model and Oxford model) and vocabulary knowledge (high and low level) on language Japanese listening skill. Previous research has found that vocabulary knowledge is related and is a powerful predictor of listening comprehension. The difference that occured in this research can be explained by the explanation of Jeremy Cross (2011), who in his research found that only one of four advance learners showed an increase in ability. According to him, there may be a tendency of decrease of the effect of the pedagogic cycle on learners' performance along with the increase in their abilities.

Another explanation that strengthens the difference between this research and previous research is the difficulty of scaffolding in online listening strategy instruction, especially the one that is given in a limited time. Online learning during a pandemic can result in the loss of aspects of scaffolding which caused learners to have difficulty in reaching understandings, especially those related to new concept or experience (Owusu-Fordjour et al., 2020).

Some of the limitations of this research are online learning during a pandemic caused limited space for teachers to provide treatment and also limited participation from learners. The online treatment in this study utilizes a video conference application that does not have a breaking room feature to divide participants into several smaller groups to facilitate their discussion. This research is a quasi-experimental study involving a group of participants in a class that is already available. The treatment time in this study is limited because it related to the learning time that has been determined by the school authority, especially during the pandemic situation. Experimental treatment with a longer time is suggested for future research.

\section{CONCLUSION}

This research aims to investigate empirical data related to the effect of online listening strategy instruction (integrative model and Oxford model) with the moderator variable vocabulary knowledge on listening skills of grade 12 Japanese language learners of SMAN 21 Bekasi. The online listening strategy instruction, integrative model has no effect on the listening skills of grade 12 Japanese language learners of SMAN 21 Bekasi. This is indicated by the absence of a significant difference between the listening skill test results of the group using the online listening strategy instruction, integrative model and the group using the online listening strategy instruction, Oxford model.

Online listening strategy instruction, integrative model and high vocabulary knowledge have no effect on the listening skills of grade 12 Japanese language learners of SMAN 21 Bekasi. This can be seen from the results of the listening skills test of students with high vocabulary knowledge in the group that used the online listening strategy instruction, integrative model not higher than the group using the online Oxford model.

The online listening strategy instruction, integrative model and low vocabulary knowledge also had no effect on the Japanese listening skills of grade 12 Japanese language learners of SMAN 21 Bekasi. This is explained by the results of 
the listening skills test of students with low vocabulary knowledge in the group using the online listening strategy instruction, integrative model was not higher than the group using the online Oxford model.

Online listening strategy instruction and vocabulary knowledge have no interaction with the Japanese listening skills of grade 12 Japanese language learners of SMAN 21 Bekasi. This can be seen from the online listening strategy instruction, integrative model in both the high vocabulary group and the low vocabulary knowledge group is less effective so that the increase in students' listening skills is not significant.

The online listening strategy instruction, integrative model was not strong enough to improve the Japanese listening skills of grade 12 Japanese language learners of SMAN 21 Bekasi. Therefore, the use of this method with online mode in grade 12 Japanese language learners of SMAN 21 Bekasi cannot be done. The effectiveness of this method may also be influenced by the length of time of treatment given, student characteristics, and the online learning design used.

Some recommendations that can be given are the Japanese language teacher of grade 12 of SMAN 21 Bekasi, not recommended to use the online listening strategy instruction, integrative model in an effort to improve the listening skills. Researchers can carry out further research to explore online instruction designs that are suitable for online listening strategy instruction, integrative model and also the involvement such as learning independence as a moderating variable that might affect this method on Japanese listening skills.

\section{REFERENCES}

Almusharraf, N. M., Khahro, S. H., \& Arabia, S. (2020). Students'

Satisfaction with Online Learning
Experiences During the COVID-19

Pandemic. IJET, 15(21), 246-267.

Bernard, R. M., Borokhovski, E., Schmid, R. F., Tamim, R. M., \& Abrami, P. C. (2014). A meta-analysis of blended learning and technology use in higher education: From the general to the applied. Journal of Computing in Higher Education. https://doi.org/10.1007/s12528-0139077-3

Brown, H. D. (2007). Teaching by Principles, An Interactive Approach to Language Pedagogy (3rd ed.). New York: Pearson Education, Inc. Retrieved from http://en.bookfi.net/book/1392129

Chamot, A. U. (2005). Language Learning Strategy Instruction: Current Issues And Research. Annual Review of Applied Linguistics, 25, 112-130.

Chen, A. (2009). Listening strategy instruction: exploring Taiwanese college students' strategy development. Asian EFL Journal.

Cohen, A. (2003). Strategy Training for Second Language Learners, 1-9.

Cross, J. (2011). Metacognitive Instruction for Helping Listeners. ELT Journal, 65(4), 408-416. https://doi.org/10.1097/ID.0b013e318 $27 \mathrm{c} 8 \mathrm{~d} 93$

Cross, J. (2012). Listening strategy instruction (or extensive listening?): A response to Renandya (2012). ELTWorldOnline.Com, 4(June), 1-6.

Field, J. (2002). The Changing Face of Listening. In J. C. Richards \& W. Renandya (Eds.), Methodology in Language Teaching: An Anthology of Current Pratice (pp. 242-247). New York: Cambridge University Press.

Gay, L. R., Mills, G. E., \& Airasian, P. (2012). Educational Research: Competencies for Analysis and Applications (10th ed.). Boston: Pearson Education, Inc.

Graham, S., \& Macaro, E. (2008). Strategy Instruction in Listening for Lower- 
Intermediate Learners of French. Language Learning, 58(4), 747-783. https://doi.org/10.1111/j.14679922.2008.00478.x

Griffiths, C. (2004). Language Learning Strategies: Theory and Research. Auckland.

Guan, Y. (2014). The effects of explicit listening strategy instruction on the listening comprehension of English as second language (ESL) community college students. ProQuest Dissertations and Theses.

Nartiningrum, N. (2020). Online Learning amidst Global Pandemic : EFL Students ' Challenges, Suggestions, and Needed Materials. ENGLISH FRANCA: Academic Journal of English Language and Education, 4(2), 115-140. https://doi.org/10.29240/ef.v4i2.1494

Nunan, D. (2002). Listening in Language Learning. In J. C. Richards \& W. A. Renandya (Eds.), Methodology in Language Teaching: An Anthology of Current Pratice (pp. 238-241). New York: Cambridge University Press.

O'Malley, J. M., Chamot, A. U., StewnerManzanares, G., Russo, R. P., Küpper, L., \& Kupper, L. (1985). Learning Strategy Applications with Students of English as a Second Language. TESOL Quarterly, 19(3), 557. https://doi.org/10.2307/3586278

Owusu-Fordjour, C., Koomson, C. K., \& Hanson, D. (2020). European Journal of Education Studies THE IMPACT OF COVID-19 ON LEARNING -. European Journal of Education Studies, 7(3), 88-101. https://doi.org/10.5281/zenodo.37535 86

Oxford, R., Crookall, D., Cohen, A., Lavine, R., Nyikos, M., \& Sutter, W. (1990). Strategy Training for Language Learners: Six Situational Case Studies and a Training Model. Foreign Language Annals, 23(3), 197-216. https://doi.org/10.1111/j.19449720.1990.tb00360.x

Oxford, R. L. (2003). Language learning styles and strategies: Concepts and relationships. IRAL - International Review of Applied Linguistics in Language Teaching, 41(4), 1-25. https://doi.org/10.1515/iral.2003.012

Richards, J. C. (2005). Second Thoughts on Teaching Listening. RELC Journal, 36(1), 85-92. https://doi.org/10.1177/00336882050 53484

Richards, J. C., \& Schmidt, R. (2010). Longman Dictionary of Language Teaching \& Applied LInguistics (4th ed.). Harlow: Pearson Education Limited.

Rost, M. (2011). Teaching and Researching Listening (2nd ed.). Harlow: Pearson Education Limited. https://doi.org/10.1016/j.jeap.2012.10. 004

Stæhr, L. S. (2009). Vocabulary Knowledge and Advanced Listening Comprehension in English as a Foreign Language. Studies in Second Language Acquisition (Vol. 31). https://doi.org/10.1017/S0272263109 990039

Vandergrift $\uparrow$, L., \& Cross, J. (2018). Cognitive Listening Strategies. The TESOL Encyclopedia of English Language Teaching, 1-6. https://doi.org/10.1002/97811187842 35.eelt0582

Vandergrift, L. (2004). Listening To Learn or Learning To Listen? Annual Review of Applied Linguistics, 24, 325. https://doi.org/10.1017/S0267190504 000017

Vandergrift, L. (2007). Recent Developments in Second and Foreign Language Listening Comprehension Research. Language Teaching, 40(3), 191-210. https://doi.org/10.1017/S0261444807 004338 
Vandergrift, L., \& Tafaghodtari, M. H. (2010). Teaching L2 Learners How to Listen Does Make a Difference: An Empirical Study. Language Learning, 60(2), 470-497. https://doi.org/10.1111/j.14679922.2009.00559.x

Wang, Y., \& Treffers-Daller, J. (2017). Explaining listening comprehension among L2 learners of English: The contribution of general language proficiency, vocabulary knowledge and metacognitive awareness. System, 65, 139-150.

https://doi.org/10.1016/j.system.2016. 12.013

Yokoyama, N. (2008). Kikukotowooshieru. Tokyo: Hitsuji Shobo. 